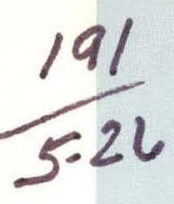

\title{
PURIFICATION OF BORON COMPOUNDS BY PYROHYDROLYSIS
}

C. R. Schmitt

R. K. Edwards

\section{UNION CAREIDE CORPORATION}

\section{NUCLEAR DIVISION} OAK RIDGE Y-12 PLANT

operated for the ATOMIC ENERGY COMMISSION under U. S. GOVERNMENT Contract W-7405 eng 26 


\section{DISCLAIMER}

This report was prepared as an account of work sponsored by an agency of the United States Government. Neither the United States Government nor any agency Thereof, nor any of their employees, makes any warranty, express or implied, or assumes any legal liability or responsibility for the accuracy, completeness, or usefulness of any information, apparatus, product, or process disclosed, or represents that its use would not infringe privately owned rights. Reference herein to any specific commercial product, process, or service by trade name, trademark, manufacturer, or otherwise does not necessarily constitute or imply its endorsement, recommendation, or favoring by the United States Government or any agency thereof. The views and opinions of authors expressed herein do not necessarily state or reflect those of the United States Government or any agency thereof. 


\section{DISCLAIMER}

Portions of this document may be illegible in electronic image products. Images are produced from the best available original document. 
Printed in the United States of America. Available from National Technical Information Service

U.S. Department of Commerce

5285 Port Royal Road, Springfield, Virginia 22151

Price: Printed Copy \$3.00; Microfiche \$0.95

This report was prepared as an account of work sponsored by the United States Government. Neither the United States nor the United States Atomic Energy Commission, nor any of their employees, nor any of their contractors, subcontractors, or their employees, makes any warranty, express or implied, or assumes any legal liability or responsibility for the accuracy, completeness or usefulness of any information, apparatus, product or process disclosed, or represents that its use would not infringe privately owned rights.

Reference to a company or product name does not imply approval or recommendation of the product by Union Carbide Corporation or the U S Atomic Energy Commission to the exclusion of others that may meet specifications. 


\title{
PURIFICATION OF BORON COMPOUNDS BY PYROHYDROLYSIS
}

\author{
C. R. Schmitt
}

R. K. Edwards

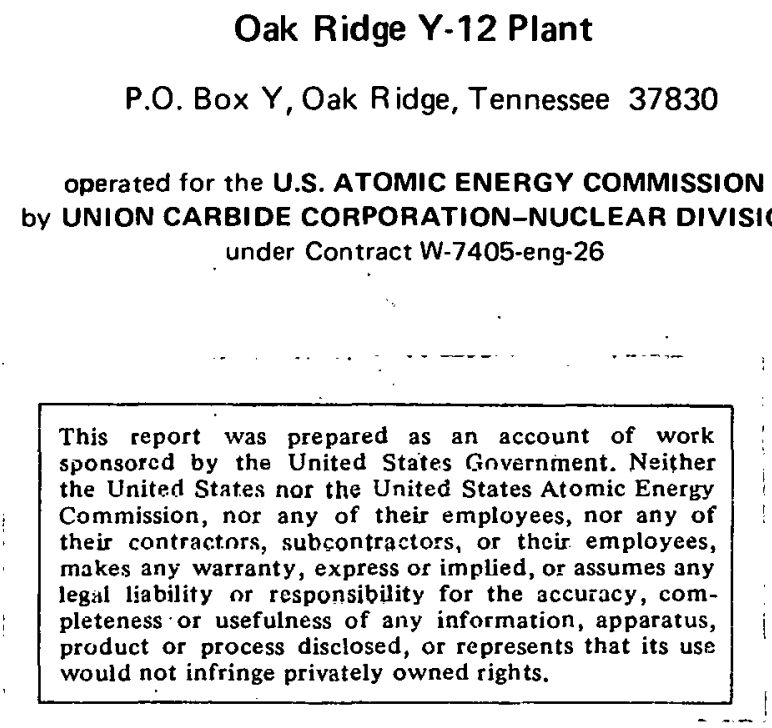

Date Issued - May 28, 1971 
Document $Y-1756$

TID-4500

\section{DISTRIBUTION}

Atomic Energy Commission-ORO

Hardison, E. H.

Keller, C. A.

Marlino, P. J. (3)

Noto, A. R.

Zachry, D. S., Jr

Atomic Energy Commission-Rocky Flats

Ritter, R. J.

Lawrence Radiation Laboratory

Cady, W. E.

Perl, H. N.

Rubin, $B$.

Weiss, $\mathrm{H}$.

Los Alamos Scientific Laboratory

Taub, J. M.

Oak Ridge Gaseous Diffusion Plant

Jordan, R. G.

Wilcox, W. J., Jr

Oak Ridge Y-12 Plant

Bernander, N. K.

Briscoe, O.W.

Burditt, R. B.

Burkhart, L. E.

Denny, A. (2)

Duerksen, W. K.

Edwards, R. K. (5)
Evans, G. W.

Foulk, D. L.

Francke, H. C. (3)

Haeusler, K. R.

Hemphill, L. F.

Jamieson, R. L., Jr

Jones, W. F.

Keele, L. D.

Keith, Alvin

Kite, H. T.

Marrow, G. B. (2)

McLendon, J. D.

Mitchel, G.W.

Perdue, H. L.

Schmitt, C. R. (15)

Schreyer, J. M.

Smith, R. D.

Steckel, L. M.

Tench, F. M.

Tewes, W. E. (2)

Trent, $P$.

Trotter, T. C.

Viator, R. A.

Wayland, H. P.

Weathersby, W. E.

Wesley, R. L.

Williams, R. D.

Yaggi, W. J.

Y-12 Central Files (5)

$Y-12$ Central Files (master copy)

$Y-12$ Central Files (route)

$Y-12$ Central Files $(Y-12 R C)$

Paducah Gaseous Diffusion Plant

Winkel, R. A. 
Sandia-Albuquerque

Berry, L. M.

Frye, E. R.

Sandia-Livermore

Adolphson, D. R.

Brierly, J. M.

Seholor, G. L.

In addition, this report is distributed in accordance with the category UC-4, Chemistry, as given in the "USAEC Standard Distribution Lists for Unclassified Scientific and Technical Reports", TID-4500. 
THIS PAGE ,

WAS INTENTIONALLY

LEFT BLANK

, 


\section{ABSTRACT}

Laboratory studies were made concerning the steam pyrohydrolysis treatment of impure elemental boron powders and potassium fluoborate powder, recovery and purification of boric acid by recrystallization from water and alcohol solutions, and the effects of various materials of construction on the purity of the recrystallized boric acid. 


\section{CONTENTS}

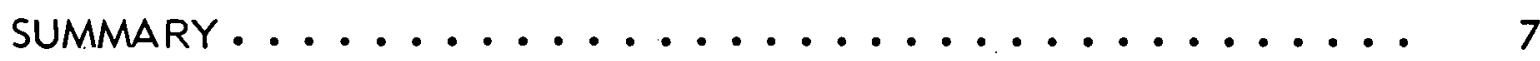

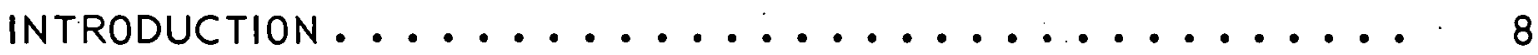

PYROHYDROLYSIS PURIFICATION OF BORON COMPOUNDS. . . . . 9

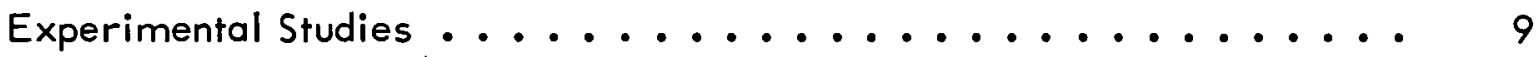

Boron Pyrohydrolysis ......................... 9

Improved Pyrohydrolysis Apparatus............. 10

Thermogravimetric-Differential Thermal Analyses ....... . 11

Potassium Fluoborate Pyrohydrolysis............. 12

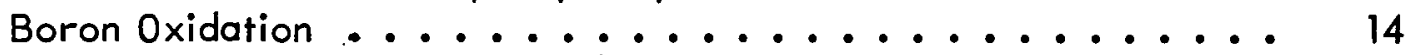

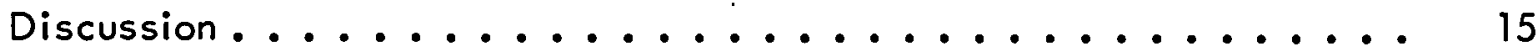

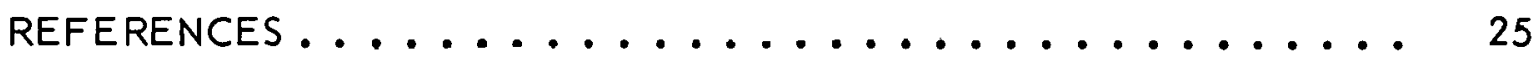

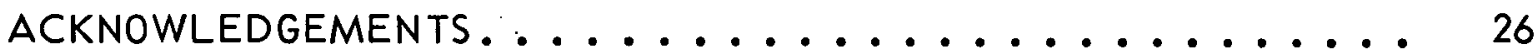


Laboratory studies were made on the recovery and purification of boric acid from impure boron and boron-containing compounds by steam pyrohydrolysis at $950^{\circ} \mathrm{C}$ followed by recrystallization from water and alcohol solutions. The effects of various materials of construction on the purity of the recrystallized boric acid were al so evaluated.

Recrystallized boric acid made by steam pyrohydrolysis of an impure boron powder and potassium fluoborate powder resulted in boric acid crystals having a total spectrographic impurity content of 58 and 106 parts per million, respectively. 


\section{INTRODUCTION}

The increasing practical and theoretical importance of the chemistry of boron has attracted the attention of numerous research workers. $(1,2)$ The potential use of boron and its compounds in semiconductor devices, high-energy fuels, protective coatings, structural materials, and numerous other applications prompted a study of methods for the preparation, purification, and characterization of ultra high-purity boron and boron compounds. Also, the Atomic Energy Commission, through its Oak Ridge Operations office, has maintained a continuing interest in the boron field with respect to producing powdered metallic boron, enriched in B-10, of a high-purity and crystalline nature, and previous related studies at the Oak Ridge $Y-12$ Plant $(a)$ on the crystallization and purification of boron metal powder have been reported. ${ }^{(3)}$

Variables affecting the preparation of high-purity boron nitride by the Ingles and Popper method $(4)$ have been studied at $Y-12$. (5) Purification of refractory materials such as boron nitride and boron carbide to remove oxygen impurities by water vapor-air mixtures was also reported by Mercuri and Litz. ${ }^{(6)}$ Eberle, et al, $(7)$ developed a process for the recovery of boron- 10 by pyrohydrolysis in a nickel reaction tube followed by treatment with potassium and hydrofluoric acid to form potassium fluoborate $\left(\mathrm{KBF}_{4}\right)$.

(a) Operated for the US Atomic Energy Commission by the Union Carbide Corporation's Nuclear Division. 


\section{PYROHYDROLYSIS PURIFICATION OF BORON COMPOUNDS}

\section{EXPERIMENTAL STUDIES}

\section{Boron Pyrohydrolysis}

Preliminary steam pyrohydrolysis studies were made on an impure elemental buion powdor to evaluate the varinus corrosion-resistant materials of construction for the furnace tube, tube liner, and boron powder containment vessel and their effects on the purity of the boric acid that was recovered by recrystallization from water and methyl alcohol media.

A series of boron-steam pyrohydrolysis runs was made for 3, 8.5, 12, 16, and 21 hours in a horizontal-tube furnace containing a three-inch-diameter by 32-inch-long quartz tube fitted with a tapered 90 -degree quartz end tube. The pyrohydrolysis atmosphere was provided by bubbling filtered, plant instrumentquality air at a flow rate of 55 cubic centimeters per minute through a flask of boiling demineralized water. The steam flow rate ranged from 160 to 200 cubic centimeters per hour. The outlet gases from the reaction tube were either condensed by bubbling directly into a cooled 500-milliliter flask of demineralized water equipped with an overflow, or a combined spiral condenser-water flask bubbler.

Effect of the reaction time on the amount of nonvolatile boat residues obtained is indicated in Figure 1 ; a summary of the run conditions and materials of construction that were tried is given in Table 1.

Spectrographic analyses showing the purity of steam-pyrohydrolyzed and waterrecrystallized boric acid crystals obtained using quartz and Inconel furnace tube materials for pyrohydrolysis are reported in Table 2. Spark-source mass spectrographic analyses, comparing the purity of steam-pyrohydrolized boric acid recrystallized from water and a dual water-methyl alcohol recrystallization treatment are listed in Table 3.

As shown in Table 3, relatively high chromium, iron, and silicon contamination was experienced in both the water and water-alcohol recrystallized boric acid when Inconel boats and an Inconel-lined quartz tube were used, because of the corrosive interaction of the pyrohydrolyzed gaseous constituents with these materials. Also, Table 3 indicates that no improvement in the general purity of the recovered boric acid crystals resulted from the use of a dual water and methyl alcohol treatment. 


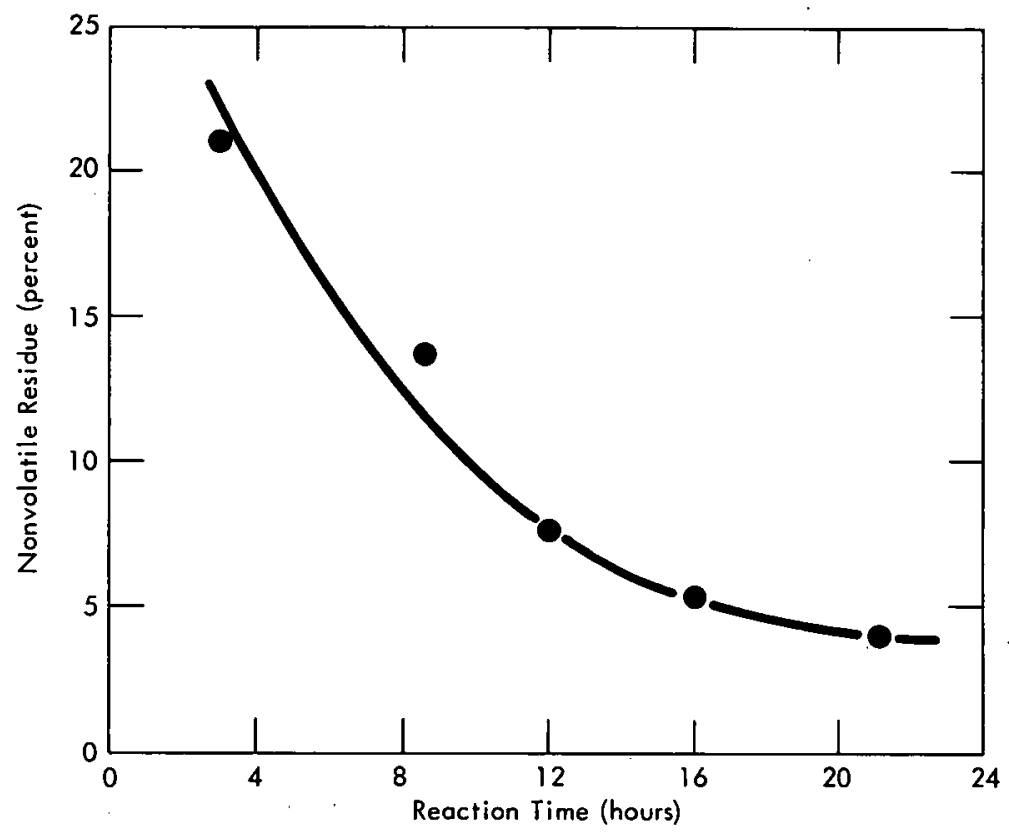

Figure 1. EFFECT OF THE BORON-STEAM PYROHYDROLYSIS TIME AT $900^{\circ} \mathrm{C}$ ON THE.RESIDUE WEIGHT.

\section{Improved Pyrohydrolysis Apparatus}

An improved apparatus was constructed for the pyrohydrolysis of impure boron or potassiuin fluuborate to make it possible to recover purified boric acid by recrystallization from a water solution. A schematic representation of the pyrohydrolysis apparatus is seen in Figure 2.

Using the pyrohydrolysis apparatus shown in Figure 2, a steam-air mixture was led into a high-purity aluminum oxide (Alundum) reaction tube and passed over the impure boron or boron-containing sample confined in a shallow Alundum boat or tray maintained at $900^{\circ} \mathrm{C}$. The boron was converted to the oxide which was then steam distilled and condensed in a Pyrex vessel containing a suitable volume of high-purity demineralized water. ${ }^{(8)}$ The Pyrex condenser was enclosed in a surrounding polyethylene container containing flowing water which served as the cooling jacket.

A summary of the spectrographic analyses of the starting impure-grade boron- 10 powder $(87.7 \% \mathrm{~B})$ and a batch of the laboratory-purified boric acid and analyticalgrade commercial boric acid crystals is given in Table 4. As shown in Table 4, boric acid crystals having a total spectrographic impurity content of approximately 58 parts per million can be recovered from an impure elemental boron powder by steam pyrohydrolysis and recrystallization from demineralized water. For this preparation, a high-purity aluminum oxide boat and furnace tube were used for pyrohydrolysis. 
Table 1

RESULTS OF THE STEAM PYROHYDROLYSIS OF BORON POWDER AT $900^{\circ} \mathrm{C}$

\begin{tabular}{|c|c|c|c|c|c|}
\hline & \multicolumn{5}{|c|}{ Run Number } \\
\hline & 1 & 2 & 3 & 4 & 5 \\
\hline Reaction Time (hours) & 3.0 & 8.5 & 12.0 & 16.0 & 21.0 \\
\hline Boron Powder (gms) $(1)$ & 10.0 & 10.0 & 10.0 & 10.0 & 10.0 \\
\hline Residue Weight (gms) & 21.1 & 13.8 & 7.7 & 5.3 & 4.9 \\
\hline Steam Flow Rate $(\mathrm{cc} / \mathrm{min})$ & 160 & 159 & 146 & 214 & 200 \\
\hline Air Flow Rate $(\mathrm{cc} / \mathrm{min})$ & 340 & 500 & 500 & 500 & 500 \\
\hline Boat Material & Inconel & Inconel & Quartz & Alundum & Alundum \\
\hline Furnace Tube Material & Quartz & Quartz & Quartz & Quuits & Quortz \\
\hline Furnace Liner Material & Inconel & Inconel & Inconel & None & None \\
\hline Condensation Equipment & Water Bubbler & Water Bubbler & Water Bubbler & $\begin{array}{l}\text { Spiral } \\
\text { Condenser } \\
\text { and Water } \\
\text { Bubbler }\end{array}$ & $\begin{array}{l}\text { Spiral } \\
\text { Condenser } \\
\text { and Water } \\
\text { Bubbler }\end{array}$ \\
\hline
\end{tabular}

(1) An impure grade of boron powder that analyzed 84.3 percent boron (See Table 5).

It was also found in studies with an impure, normal-boron-assay starting material that a fairly large amount of nonvolatile residue (ie, $5 \%$ ) resulted from the steam pyrohydrolysis treatment. Chemical and semiquantitative spectrochemical analyses of this relatively impure, commercially obtained, elemental normal-boron powder that was used for these steam pyrohydrolysis studies (and in subsequent air and nitric acid oxidation studies) are summarized in Table 5.

$X$-ray diffraction analyses of the nonvolatilized boat residue from the impure, normal-boron material showed the presence of magnesium tetraborate $\left(\mathrm{MgB}_{4} \mathrm{O}_{7}\right)$ after 12 hours reaction time and magnesium borate $\left(\mathrm{Mg}_{2} \mathrm{~B}_{2} \mathrm{O}_{5}\right)$ after 16 to 24 hours reaction time. These residue analyses show that most of the two percent magnesium impurity content of the starting normal boron powder (Table 5) remains as a nonvolatile pyrohydrolysis product which can be discarded. $X$-ray diffraction patterns of the nonvolatile residue materials after pyrohydrolysis treatment are presented in Figure 3.

Thermogravimetric-Differential Thermal Analyses

Commercial, reagent-grade boric acid crystals and recrystallized boric acid crystals that had been laboratory prepared by steam pyrohydrolysis of an impure boron powder (Table 5) were compared by simultaneous thermogravimetric and differential thermal analyses. After evacuating to 50 micrometers $(\mathrm{Hg})$ and backfilling with argon, both samples were heated at a rate of $6^{\circ} \mathrm{C}$ per minute to $400^{\circ} \mathrm{C}$. The commercial boric acid showed a total weight loss of 43.1 percent 
Table 2

SPECTROGRAPHIC ANALYSES OF LABORATORY-PREPARED BORIC ACID CRYSTALS FROM IMPURE BORON POWDER USING QUARTZ AND

INCONEL EQUIPMENT FOR PYROHYDROLYSIS

(All Values in ppm)

\begin{tabular}{|c|c|c|c|c|}
\hline \multirow[b]{2}{*}{ Element } & \multicolumn{4}{|c|}{ Run Number } \\
\hline & 1 & 2 & 3 & 4 \\
\hline Al & 4 & 4 & 10 & 15 \\
\hline As & $<10$ & $<10$ & $<10$ & $<10$ \\
\hline Au & $<\quad 1$ & $<1$ & $<1$ & $<1$ \\
\hline$B$ & Matrix & Matrix & Matrix & Matrix \\
\hline Bo & 2 & $<2$ & $<$ & $<$ \\
\hline $\mathrm{Be}$ & $<\quad 0.01$ & $<\quad 0.01$ & 0.01 & 0.02 \\
\hline $\mathrm{Bi}$ & $<\quad 1$ & $<1$ & $<1$ & $<1$ \\
\hline $\mathrm{Ca}$ & 20 & $12^{\circ}$ & $<$ & 10 \\
\hline $\mathrm{Cd}$ & $<0.10$ & $<\quad 0.10$ & 0.10 & $<\quad 0.10$ \\
\hline Co & $<1$ & $<1$ & $<$ & $<$ \\
\hline $\mathrm{Cr}$ & $<2$ & $<2$ & $<2$ & 2 \\
\hline $\mathrm{Cu}$ & 4 & 6 & 4 & 3 \\
\hline $\mathrm{Fe}$ & 10 & 60 & 45 & 15 \\
\hline Go & $<1$ & $<1$ & $<1$ & $<1$ \\
\hline $\mathrm{Ge}$ & $<1$ & $<1$ & $<1$ & $<$ \\
\hline $\mathrm{Li}$ & 0.2 & 0.2 & $<0.2$ & 0.2 \\
\hline $\mathrm{Mg}$ & 4 & 3 & 3 & 6 \\
\hline$M n$ & $<1$ & $<1$ & $<1$ & $<1$. \\
\hline Mo & $<10$ & $<10$ & $<10$ & $<10$ \\
\hline $\mathrm{No}$ & 60 & 20 & 25 & 20 \\
\hline $\mathrm{Nb}$ & $<10$ & $<10$ & $<10$ & $<10$ \\
\hline $\mathrm{Ni}$ & 10 & 3 & 1 & 2 \\
\hline$P$ & $<100$ & $<100$ & $<100$ & $<1.00$ \\
\hline $\mathrm{Pb}$ & 2 & $<1$ & $<$ & 8 \\
\hline $\mathrm{Pd}$ & $<1$ & $<$ & $<1$ & $<$ \\
\hline $\mathrm{Sb}$ & $<2$ & $<$ & $<2$ & 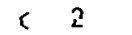 \\
\hline 31 & 25 & 30 & 50 & 40 \\
\hline Sn & $<1$ & $<1$ & $<1$ & 2 \\
\hline $\mathrm{Sr}$ & $<20$ & $<20$ & $<20$ & $<20$ \\
\hline $\mathrm{Ti}$ & $<4$ & $<4$ & $<4$ & $<4$ \\
\hline $\mathrm{V}$ & $<1$ & $<1$ & $<1$ & $<1$ \\
\hline W & $<100$ & $<100$ & $<100$ & $<100$ \\
\hline $\mathrm{Zn}$ & $<10$ & $<10$ & $<10$ & $<10$ \\
\hline Totál(1) & 111 & 138 & 138 & 123 \\
\hline $\begin{array}{l}\text { Boat Material } \\
\text { Furnace Tube Material } \\
\text { Furnace Liner Material }\end{array}$ & $\begin{array}{l}\text { Quartz } \\
\text { Quartz } \\
\text { None }\end{array}$ & $\begin{array}{l}\text { Inconel } \\
\text { Quartz } \\
\text { Inconel }\end{array}$ & $\begin{array}{l}\text { Alundum } \\
\text { Quartz } \\
\text { Inconel }\end{array}$ & $\begin{array}{l}\text { Alundum } \\
\text { Quartz } \\
\text { None }\end{array}$ \\
\hline
\end{tabular}

(1) Exclusive of less-than values.

and the laboratory-prepared boric acid showed a weight loss of 43.9 percent. Thermograms of these two boric acid materials, shown in Figures 4 and 5 , are quite analogous.

Potassium Fluoborate Pyrohydrolysis

For potassium fluoborate $\left(\mathrm{KBF}_{4}\right)$, a steam-air pyrohydrolysis treatment of approximately six hours at $500^{\circ} \mathrm{C}$ was sufficient to volatilize the material, and 
Table 3

SPARK SOURCE MASS SPECTROGRAPHIC ANALYSES OF RECRYSTALLIZED BORIC ACID FROM STEAM PYROHYDROLYSIS OF IMPURE BORON POWDER

\begin{tabular}{|c|c|c|c|c|c|c|c|c|}
\hline \multicolumn{4}{|c|}{ Water Recrystallization } & \multicolumn{5}{|c|}{ Water and MethylAlcohol Recrystallization } \\
\hline Element & $\mathrm{ppm}$ & Element & ppm & Element & ppm & Element & & $\mathrm{ppm}$ \\
\hline $\mathrm{Al}$ & 7.8 & Nd & $<1.9$ & $\mathrm{Al}$ & 72.4 & Nd & $<$ & 1.8 \\
\hline As & $<0.7$ & $\mathrm{Ni}$ & 4.2 & As & 1.0 & $\mathrm{Ni}$ & & 7.7 \\
\hline Au & $<1.9$ & Os & $<1.4$ & Au & 1.8 & Os & $<$ & 1.4 \\
\hline Ba & $<0.6$ & P & 2.3 & Bo & $<1.7$ & $\mathbf{P}$ & & 13.8 \\
\hline $\mathrm{Bi}$ & $<0.6$ & $\mathrm{~Pb}$ & 1.5 & $\mathrm{Bi}$ & 1.8 & $\mathrm{~Pb}$ & & 5.4 \\
\hline $\mathrm{Br}$ & $<1.5$ & $P d$ & $<1.2$ & $\mathrm{Br}$ & 1.4 & $\mathrm{Pd}$ & $<$ & 1.2 \\
\hline Ca & 65.0 & $\mathrm{Pr}$ & $<0.4$ & $\mathrm{Ca}$ & 36.9 & Pr & $<$ & 0.4 \\
\hline $\mathrm{Cd}$ & $=3.8$ & Pt & $<1.8$ & $\mathrm{Cd}$ & $<1.2$ & PI & $<$ & 1.7 \\
\hline $\mathrm{Ce}$ & $<0.5$ & $\mathrm{Rb}$ & $<1.2$ & $\mathrm{Ce}$ & $<0.4$ & $\mathrm{Rb}$ & $<$ & 0.4 \\
\hline Co & 0.6 & $\operatorname{Re}$ & $<1.0$ & Co & 0.5 & $\operatorname{Re}$ & $<$ & 0.8 \\
\hline $\mathrm{Cr}$ & 20.2 & Rh & $<0.3$ & $\mathrm{Cr}$ & 55.8 & Rh & $<$ & 0.3 \\
\hline Cs & $<1.2$ & Ru & $<1.0$ & Cs & $<1.2$ & Ru & $<$ & 1.0 \\
\hline $\mathrm{Cu}$ & 8.9 & $\mathrm{Sb}$ & $<0.6$ & Cu & 2.7 & $\mathrm{Sb}$ & $<$ & 0.6 \\
\hline Dy & $<1.8$ & $3 c$ & $0: 4$ & Dy & < 1.7 & Sc & & 0.4 \\
\hline $\mathrm{Er}$ & $<1.6$ & Se & $<1.5$ & $\mathrm{Er}$ & $<1.4$ & Se & & 1.4 \\
\hline Eu & $<0.9$ & Si & 58.3 & Eu & $<0.8$ & $\mathrm{Si}$ & & 161.2 \\
\hline $\mathrm{Fe}$ & 19.6 & Sm & $<1.8$ & $\mathrm{Fe}$ & 18.2 & Sm & $<$ & 1.6 \\
\hline $\mathrm{Ga}$ & $<1.1$ & Sn & $<4.0$ & Go & 1.0 & Sn & $<$ & 4.0 \\
\hline $\mathrm{Gd}$ & $<2.3$ & $\mathrm{Sr}$ & $<1.0$ & Gd & $<2.2$ & $\mathrm{Sr}$ & $<$ & 1.0 \\
\hline $\mathrm{Ge}$ & $<1.9$ & To & $\leq 17.6$ & $G e$ & 1.8 & $\mathrm{Ta}$ & $s$ & 16.2 \\
\hline $\mathrm{HF}$ & $<2.1$ & Tb & $<0.5$ & $\mathrm{HF}$ & $<2.0$ & $\mathrm{~Tb}$ & $<$ & 0.4 \\
\hline $\mathrm{Hg}$ & $<2.2$ & Te & $<1.2$ & $\mathrm{Hg}$ & $<2.0$ & Te & $<$ & 1.1 \\
\hline Ho & $<0.5$ & Th & $<0.7$ & Ho & $<.0 .4$ & Th & $<$ & 0.6 \\
\hline 1 & $<1.2$ & $\mathrm{Ti}$ & 21.1 & 1 & $<0.4$ & $\mathrm{Ti}$ & & 19.4 \\
\hline In. & 1.2 & TI & $<0.9$ & $\ln$ & $<0.4$ & TI & $<$ & 0.8 \\
\hline Ir & $<1.0$ & $\mathrm{Tm}$ & $<0.5$ & Ir & $<0.9$ & $\mathrm{Tm}$ & $<$ & 0.4 \\
\hline K & 0.6 & $U$ & $<0.8$ & $K$ & 2.8 & $U$ & $<$ & 0.7 \\
\hline La & $<1.4$ & $V$ & 0.4 & Lo & $<1.2$ & $V$ & & 0.4 \\
\hline Lu & $<0.6$ & $W$ & $<1.9$ & Lu & $<0.5$ & W & $<$ & 1.8 \\
\hline $\mathrm{Mg}$ & 3.5 & $Y$ & 0.8 & $\mathrm{Mg}$ & 6.4 & Y & $<$ & 0.8 \\
\hline$M_{n}$ & 0.5 & $\mathrm{Yb}$ & $<1.8$ & $M n$ & 0.4 & $Y b$ & $<$ & 1.6 \\
\hline Mo & $<1.3$ & $\mathrm{Zn}$ & 3.5 & Mo & 3.6 & $\mathrm{Zn}$ & & 2.1 \\
\hline $\mathrm{Na}$ & 0.4 & $\mathrm{Zr}$ & $<0.6$ & No & 0.5 & $\mathrm{Zr}$ & $<$ & 1.6 \\
\hline $\mathrm{Nb}$ & $<0.2$ & & & $\mathrm{Nb}$ & $<0.2$ & & & \\
\hline
\end{tabular}

Note: A quartz boat was used with an Inconel liner in a three-inch-diameter quartz tube for the $900^{\circ} \mathrm{C}$ pyrohydrolysis.

for boron metal powder a pyrohydrolysis treatment of 21 hours at $900^{\circ} \mathrm{C}$ was used. A typical analysis of the steam condensate obtained from the pyrohydrolysis of the fluoborate showed the presence of hydrofluoric acid (1.4 gms $\mathrm{HF} / \mathrm{I})$, boric acid $(0.03 \mathrm{gm} \mathrm{B/I})$, and potassium fluoride $(1.4 \mathrm{gms} \mathrm{K} / \mathrm{I})$. The boric acid was recrystallized by cooling to approximately $2^{\circ} \mathrm{C}$ and by washing the crystals with prechilled demineralized water held at approximately $2^{\circ} \mathrm{C}$.

Recrystallized boric acid made by the steam pyrohydrolysis of potassium fluoborate at $900^{\circ} \mathrm{C}$ resulted in a product having a higher purity than three samples of commercially procured boric acid. Spark-source mass spectrochemical analyses of the laboratory-prepared and commercial boric acid crystals are presented in Table 6. 


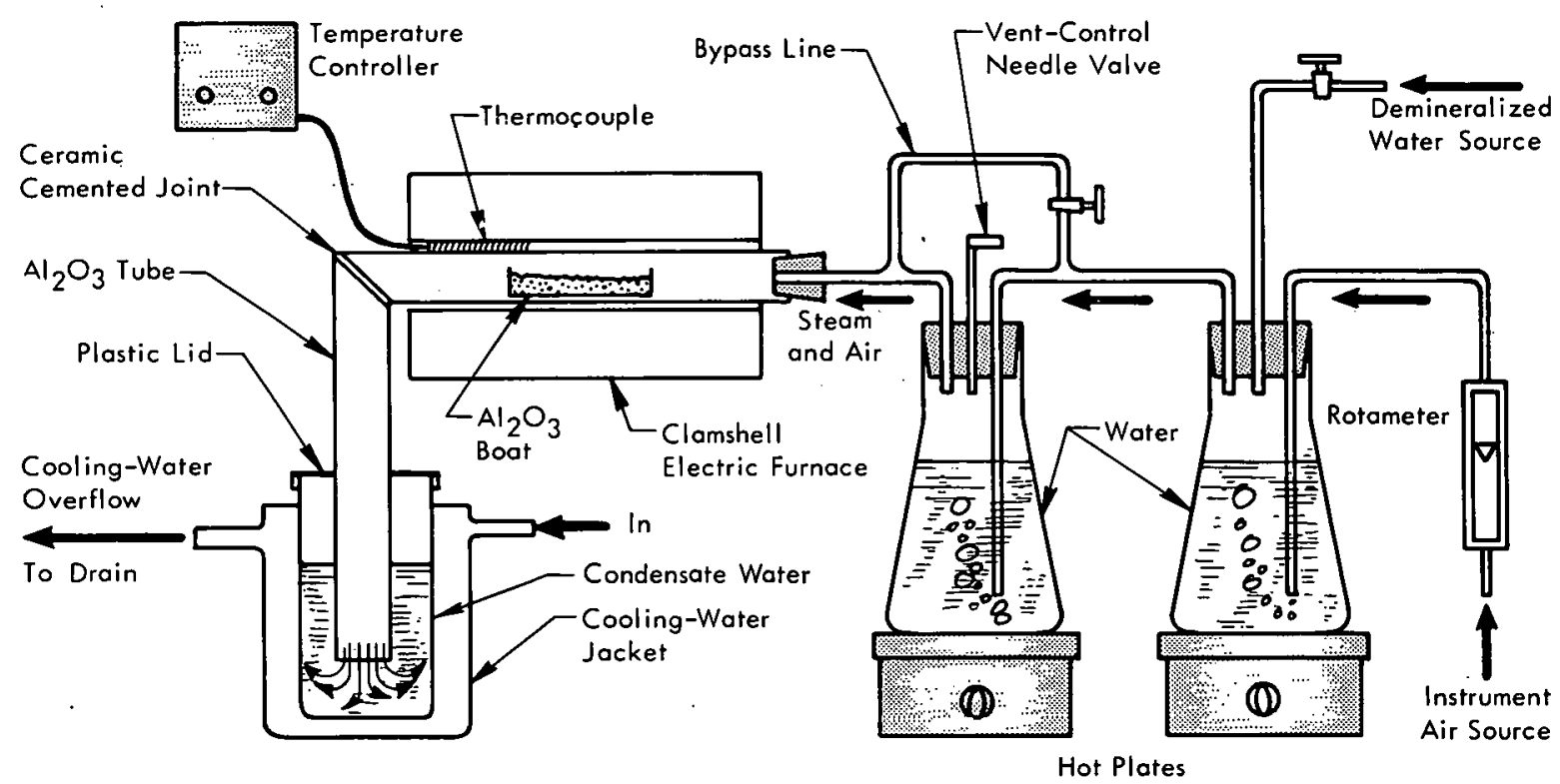

Figure 2. PYROHYDROLYSIS APPARATUS.

\section{Boron Oxidation}

Some preliminary oxidation studies on an impure boron powder (Table 5) using air and nitric acid were made in order to compare these methods with steam pyrohydrolysis. The oxidation of an impure elemental boron powder with diry, inslizument-quallty al " at a temperature of 900 to $1,000^{\circ} \mathrm{C}$ was studied using a horizontal tube furnace and a three-inch-diameter quartz rube. Alundum boats containing the powdered boron were exposed to flowing air at $900^{\circ} \mathrm{C}$ for 3,7 , and 24 hours, and weight gains were recorded. The weight gains obtained were erratic and ranged from 125 to 135 percent. It was found that the boron had sintered into a hard, glassy mass and only the surface appeared to oxidize. A photomicrograph showing the sintered boron powder and partially oxidized residue remaining from the air oxidation treatment is given in Figure 6 . The incomplete oxidation of boron and boron compounds obtained by heating in air at 900 to $1,000^{\circ} \mathrm{C}$ was also experienced by other investigators. $(9-11)$

A preliminary study of the oxidation of an impure elemental boron powder (Table 4) with nitric acid was also made by reacting one gram of boron with 200 milliliters of ten weight percent nitric acid and boiling to dryness. The residue was dissolved in water and filtered. The filtrate was evaporated until crystals appeared, placed in an ice bath to further crystallize the boric acid, refiltered, rinsed with ice water, and dried at $110^{\circ} \mathrm{C}$. Semiquantitative spectrochemical analyses of the boric acid crystals showed the presence of 0.01 percent magnesium, 0.008 percent calcium, and 0.03 percent silicon as the major impurities. 
Table 4

SPECTROGRAPHIC ANALYSES OF LABORATORY-PREPARED BORIC ACID FROM IMPURE BORON POWDER AND COMMERCIAL BORIC ACID

(All Values in ppm)

\begin{tabular}{|c|c|c|c|c|}
\hline \multirow[b]{2}{*}{ Element } & \multicolumn{2}{|c|}{ Boric Acid } & \multirow{2}{*}{\multicolumn{2}{|c|}{$\begin{array}{c}\text { Starting } \\
\text { Impure } \\
\text { Boron-10 }\end{array}$}} \\
\hline & $\begin{array}{l}\text { Laboratory } \\
\text { Prepared(1) }\end{array}$ & Commercial(2) & & \\
\hline Al & 4 & 2 & $<$ & 50 \\
\hline As & $<10$ & $<10$ & & 600 \\
\hline Au & $<1$ & $<1$ & $<$ & 200 \\
\hline B & Matrix & Matrix & & trix \\
\hline $\mathrm{Ba}$ & $<2$ & $<2$ & $<$ & 20 \\
\hline $\mathrm{Be}$ & $<\quad 0.01$ & 0.12 & $<$ & 10 \\
\hline $\mathrm{Bi}$ & $<1$ & $<1$ & $<$ & 10 \\
\hline $\mathrm{Ca}$ & 10 & 10 & & 8,000 \\
\hline $\mathrm{Cd}$ & $<\quad 0.10$ & $<\quad 0.10$ & $<$ & 400 \\
\hline Co & $<1$ & $<$ & $<$ & 50 \\
\hline $\mathrm{Cr}^{\circ}$ & $<$ & $<2$ & $<$ & 100 \\
\hline $\mathrm{Cu}$ & $<1$ & $?$ & $<$ & 6,000 \\
\hline $\mathrm{Fe}$ & $<10$ & 10 & & 2,000 \\
\hline Ga & $<1$ & $<1$ & & 1,200 \\
\hline $\mathrm{Ge}$ & $<$ & $<1$ & $<$ & 200 \\
\hline $\mathrm{Li}$ & 0.2 & $<\quad 0.2$ & & 2,500 \\
\hline $\mathrm{Mg}$ & 4 & $<2$ & & 200 \\
\hline$M n$ & $<$ & $<\quad 1$ & & 600 \\
\hline Mo & $<10$ & $<10$ & $<$ & 20 \\
\hline $\mathrm{Na}$ & 20 & 10 & & 1,500 \\
\hline $\mathrm{Nb}$ & $<10$ & $<10$ & $<$ & 200 \\
\hline $\mathrm{Ni}$ & $<10$ & $<10$ & & 1,200 \\
\hline$p$ & $<100$ & $<100$ & & - \\
\hline $\mathrm{Pb}$ & $<1$ & $<1$ & & - \\
\hline Pd & $<\quad 1$ & $<1$ & & - \\
\hline $\mathrm{Sb}$ & $<2$ & $<2$ & $<$ & 400 \\
\hline $\mathrm{Si}$ & 20 & 10 & & 1,500 \\
\hline Sn & $<1$ & $<1$ & $<$ & 50 \\
\hline $\mathrm{Sr}$ & $<20$ & $<20$ & & - \\
\hline $\mathrm{Ti}$ & $<4$ & $<$ & & - \\
\hline$\checkmark$ & $<\quad 1$ & $<1$ & く & 50 \\
\hline$w$ & $<100$ & $<100$ & $<$ & 800 \\
\hline $\mathrm{Zn}$ & $\leq 10$ & $<10$ & $<$ & 800 \\
\hline Total(3) & 58 & 44 & & 9,300 \\
\hline
\end{tabular}

(1) By steam pyrohydrolysis using an Alundum furnace tube and boat.

(2) Vendul A ieuyeiil - jrade borio aoid.

(3) Exclusive of less-ihon values.

\section{DISCUSSION}

Materials of construction for the boat and reactor tube used for the initial boron pyrohydrolysis studies included stainless steel, Inconel, Monel, and quartz, but these were generally unsatisfactory because of excessive contamination of the recrystallized boric acid with iron, copper, nickel, or silicon. When a Monel reactor tube was used, condensation of the reactor exit gases was facilitated by wrapping the Monel tube with a spiral jacket of 1/4-inch-diameter copper tubing which contained flowing cooling water. 
Table 5

ANALYSES OF ELEMENTAL NORMAL BORON POWDER USED FOR STEAM PYROHYDROLYSIS AND OXIDATION PURIFICATION STUDIES

\begin{tabular}{|c|c|c|c|}
\hline \multicolumn{4}{|c|}{ Chemical (\%) } \\
\hline Total Boron & & 84.3 & \\
\hline Oxygen & & 13.13 & \\
\hline $\mathrm{B}_{2} \mathrm{O}_{3}{ }^{(1)}$ & & 2.4 & \\
\hline \multicolumn{4}{|c|}{ Spectrochemical (\%) } \\
\hline $\mathrm{Ag}$ & $<0.005$ & Mo & $<0.002$ \\
\hline Al & $<0.01$ & $\mathrm{Na}$ & 0.012 \\
\hline Au & $<0.02$ & $\mathrm{Nb}$ & 0.012 \\
\hline B & Matrix & $\mathrm{Ni}$ & 0.01 \\
\hline Ba & $<0.002$ & $\mathbf{P}$ & $<1.0$ \\
\hline $\mathrm{Be}$ & $<0.001$ & $\mathrm{~Pb}$ & 0.01 \\
\hline $\mathrm{Bi}$ & $<0.01$ & $\mathrm{Rb}$ & 0.15 \\
\hline $\mathrm{Ca}$ & 0.15 & $\mathrm{Sb}$ & $<0.04$ \\
\hline Cd & $<0.04$ & $\mathrm{Si}$ & 0.04 \\
\hline Co & $<0.005$ & $\mathrm{Sn}$ & $<0.005$ \\
\hline $\mathrm{Cr}$ & 0.015 & $\mathrm{Ta}$ & $<0.15$ \\
\hline Cs & $<0.6$ & Th & $<0.04$ \\
\hline Cu & $<0.005$ & $\mathrm{TI}$ & $<0.01$ \\
\hline $\mathrm{Fe}$ & 0.08 & $u$ & $<0.3$ \\
\hline $\mathrm{Hf}$ & $<0.02$ & $v$ & $<0.005$ \\
\hline$K$ & $<0.04$ & W & $<0.08$ \\
\hline Li & $<0.02$ & $\mathrm{Zn}$ & $<0.08$ \\
\hline $\mathrm{Mg}$ & 2.0 & $\mathrm{Zr}$ & $<0.002$ \\
\hline$M n$ & 0.02 & & \\
\hline
\end{tabular}

(1) By a methyl alcohol extraction procedure.

The effect of temperature on the solubility of boric acid in water is indicated in Figure 7. During steam pyrohydrolysis of an impure boron compound, the hot steam and exit gases from the pyrohydrolysis reaction tube caused a considerable increase in the temperature of the demineralized water condensing bath, reaching approximately $50-60^{\circ} \mathrm{C}$, depending on the heat transfer conditions employed. As Figure 7 shows, the solubility of boric acid in water at $60^{\circ} \mathrm{C}$ is approximately 15 grams of boric acid per 100 grams of water. If a saturated boric acid solution at this temperature were filtered at $25^{\circ} \mathrm{C}$, approximately 6 grams of the boric acid per 100 grams of water would still remain in solution. By prechilling the boric acid solution to 1 or $2^{\circ} \mathrm{C}$, however, the solubility of the boric acid is only approximately 3 grams per 100 grams of water and a higher boric acid recovery efficiency can thus be obtained by filtering at the lower temperature. Although not a part of this study, boric acid solutions obtained by steam pyrohydrolysis of an impure boron compound could readily be processed further by ion exchange resins to remove any specific undesirable impurities such as the chloride or fluoride.

As reported in Tables 4 and 6, the purity of the recrystallized boric acid obtained was better than or equivalent to the purity of several commercial samples 


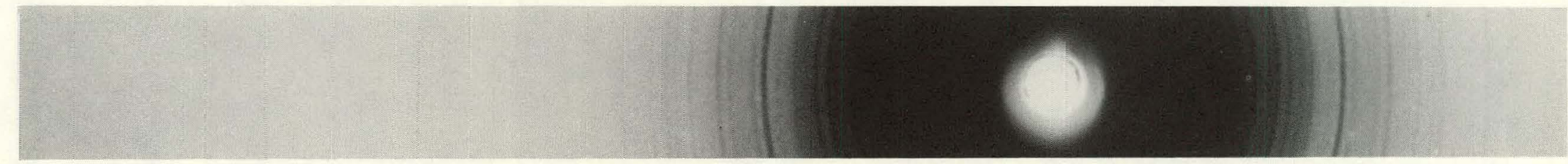

Major: $\mathrm{MgB}_{4} \mathrm{O}_{7}$ After 12 Hours Pyrohydrolysis

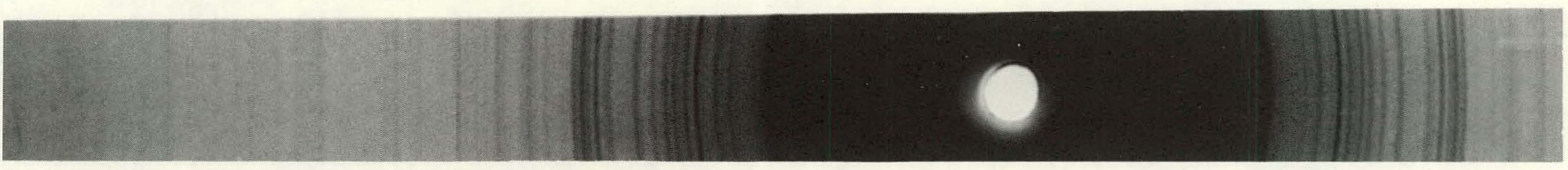

Major: $\mathrm{Mg}_{2} \mathrm{~B}_{2} \mathrm{O}_{5}$ After 16 Hours Pyrohydrolysis

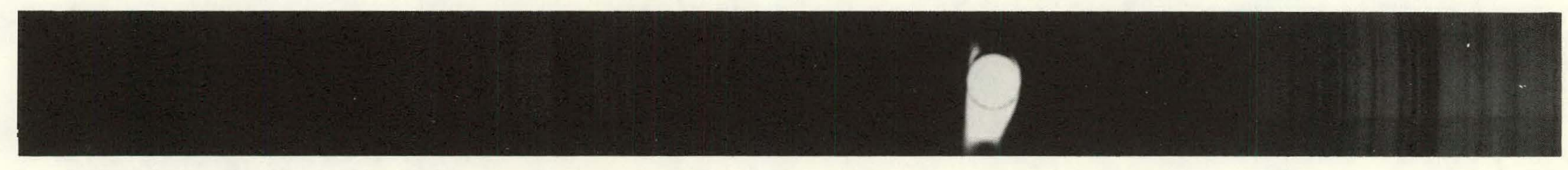

Major: $\mathrm{Mg}_{2} \mathrm{~B}_{2} \mathrm{O}_{5}$ After 24 Hours Fyrohydrolysis

Figure 3. X-RAY DIFFRACTION PATTEFNS OF NONVOLATILE RESIDUES OBTAINED FROM THE PYROHYDROLYSIS CF IMPURE BORON AT $950^{\circ} \mathrm{C}$. 


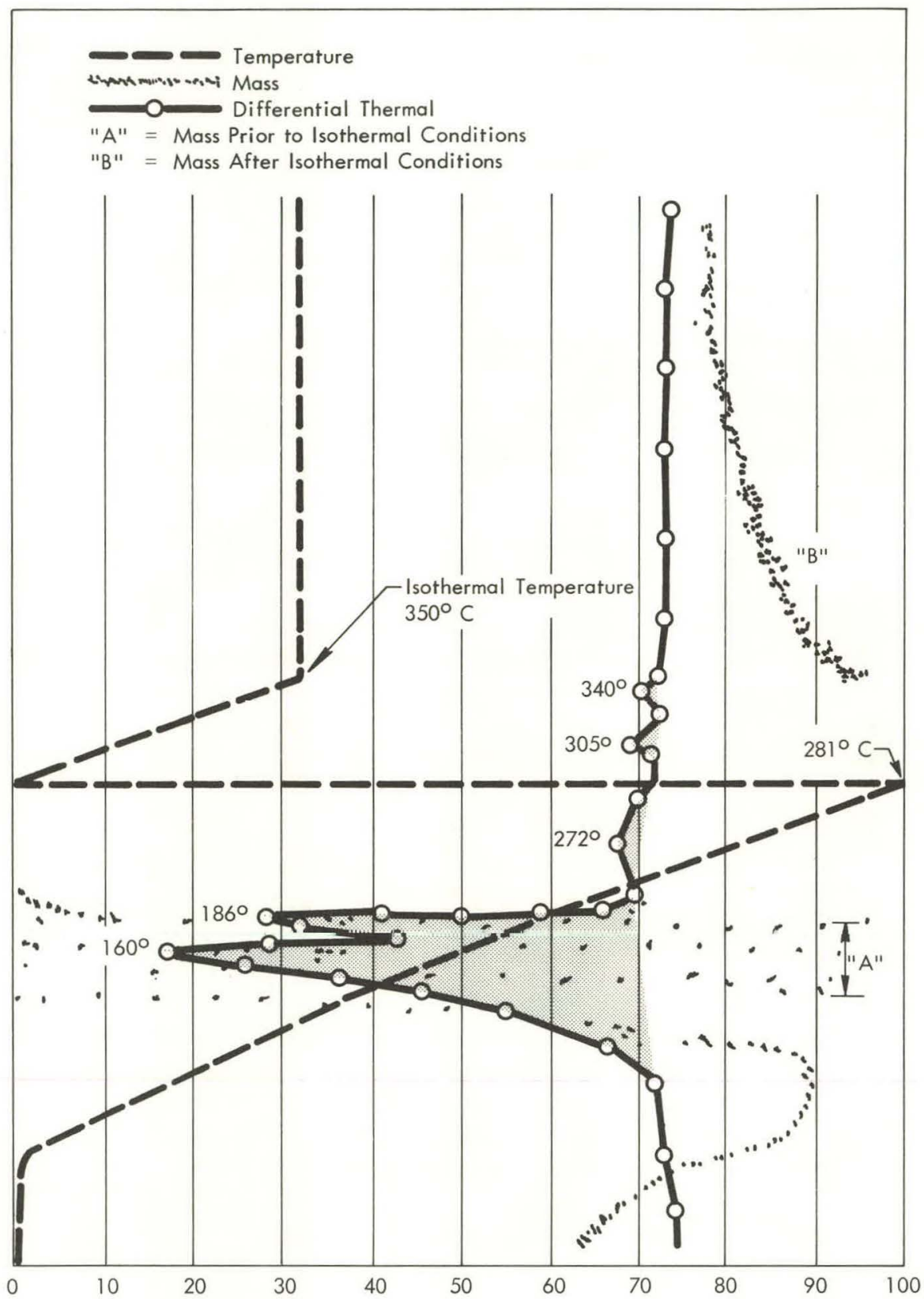

Figure 4. THERMOGRAVIMETRIC-DIFFERENTIAL THERMAL ANALYSIS OF BORIC ACID CRYSTALS MADE FROM THE STEAM PYROHYDROLYSIS OF AN IMPURE BORON.

of laboratory-grade boric acid. The purity of a commercial sample of technicalgrade boric oxide $\left(\mathrm{B}_{2} \mathrm{O}_{3}\right)$ powder shown in Table 6 was found to be greater than that of two samples of commercial laboratory-grade boric acid. It is believed that the presence of moisture may be one of the major impurities associated with technical-grade boric oxide, but this may not be a deterring factor for its use in the synthesis of many high-purity boron compounds. 


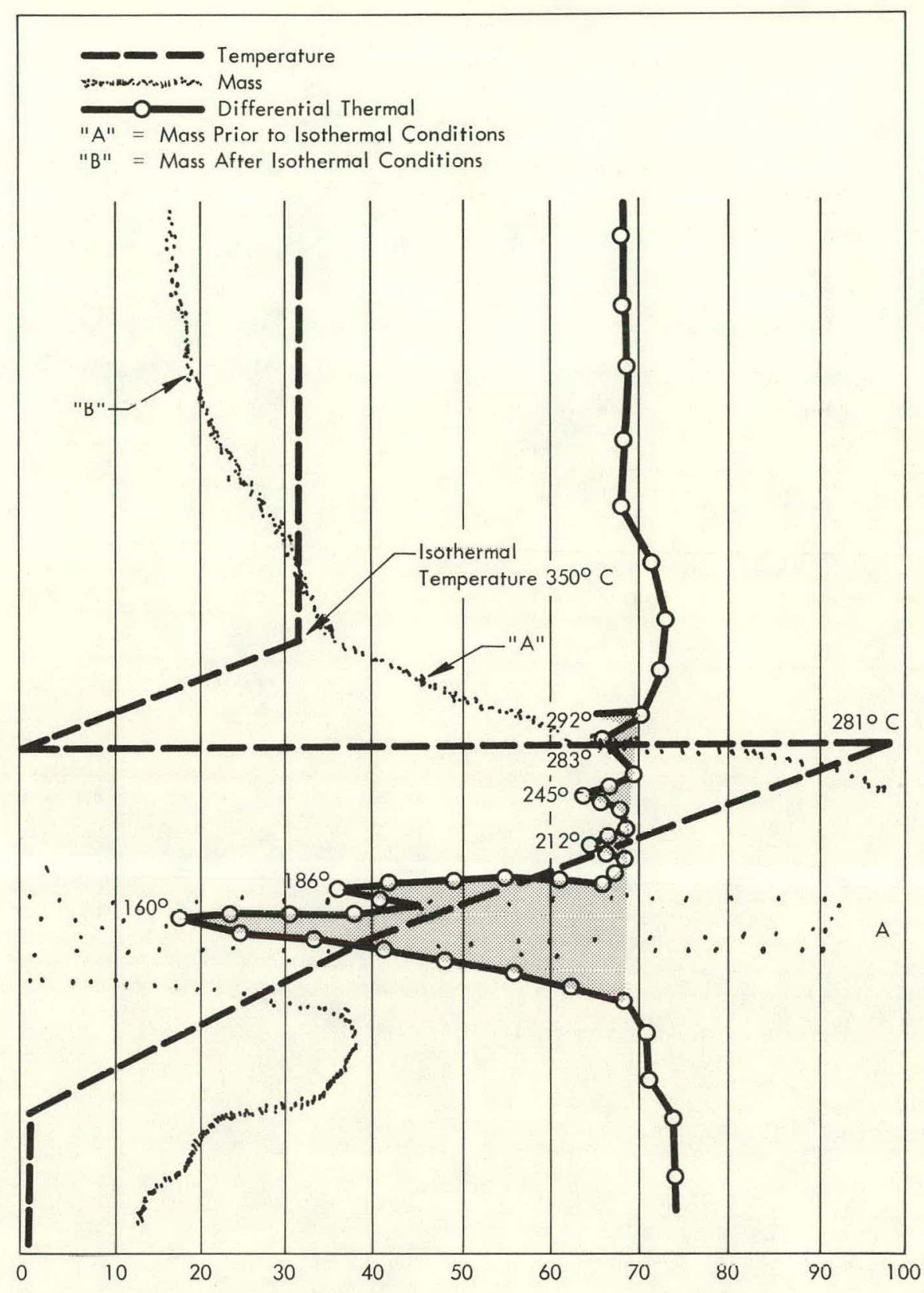

Figure 5. THERMOGRAVIMETRIC-DIFFERENTIAL THERMAL ANALYSIS OF COMMERCIAL HIGH-PURITY BORIC ACID CRYSTALS.

Although spectrochemical and spark-source mass spectrographic analyses have been used in this study to evaluate the purity of boric acid, other analytical methods may be required to further assess the general purity. A summary of the American Chemical Society purity requirements for reagent-grade boric acid is given in Table 7. (12)

As seen in Table 4, laboratory-recrystallized boric acid having an equivalent total impurity content of only 58 parts per million has been prepared from an impure borun powder by the steam pyrohydrolysis treatment. 
Table 6

SPARK-SOURCE MASS SPECTROGRAPHIC ANALYSES OF COMMERCIAL AND LABORATORY-PREPARED BORIC ACID POWDERS

(All Values in ppm)

\begin{tabular}{|c|c|c|c|c|c|c|c|c|}
\hline \multirow{2}{*}{$\begin{array}{l}\text { Element } \\
\mathrm{Al}\end{array}$} & \multicolumn{2}{|c|}{$\begin{array}{l}\text { Laboratory } \\
\text { Prepared }(Y)\end{array}$} & \multicolumn{2}{|c|}{$\begin{array}{l}\text { Technical } \\
\text { Grade(2) }\end{array}$} & \multicolumn{2}{|c|}{$\begin{array}{c}\text { Vendor } \\
\mathrm{A}(3)\end{array}$} & \multicolumn{2}{|c|}{$\begin{array}{c}\text { Vendor } \\
B(3)\end{array}$} \\
\hline & & 1.9 & & 20.0 & & 6.8 & & 8.4 \\
\hline As & $<$ & 0.6 & $<$ & 1.2 & $<$ & 1.2 & $<$ & 1.6 \\
\hline $\mathrm{Au}$ & $<$ & 4.6 & & 3.2 & $<$ & 4.8 & $<$ & 4.1 \\
\hline $\mathrm{Ba}$ & $<$ & 1.5 & $<$ & 19.6 & $<$ & 1.0 & $<$ & 1.3 \\
\hline $\mathrm{Be}$ & & 0.2 & & 0.1 & & 0.2 & & 0.6 \\
\hline $\mathrm{Bi}$ & $<$ & 4.9 & $<$ & 3.4 & $<$ & 3.4 & $<$ & 4.4 \\
\hline $\mathrm{Br}$ & $<$ & 3.2 & $<$ & 2.5 & $<$ & 2.6 & $<$ & 3.2 \\
\hline $\mathrm{Ca}$ & & 35.0 & & 22.1 & & 68.0 & & 30.0 \\
\hline $\mathrm{Cd}$ & $<$ & 3.1 & $\leq$ & 6.2 & $<$ & 2.0 & $<$ & 2.6 \\
\hline $\mathrm{Ce}$ & $<$ & 1.2 & $<$ & 0.8 & $<$ & 2.6 & $<$ & 1.1 \\
\hline Co & & 0.4 & & 1.0 & $<$ & 0.3 & $<$ & 0.4 \\
\hline $\mathrm{Cr}$ & $<$ & 2.0 & $<$ & 2.0 & $<$ & 2.0 & $<$ & 2.0 \\
\hline Cs & $<$ & 1.0 & $<$ & 2.1 & $<$ & 2.2 & $<$ & 2.8 \\
\hline $\mathrm{Cu}$ & & 3.4 & & 1.4 & & 23.0 & & 19.2 \\
\hline Dy & $<$ & 4.6 & $<$ & 9.2 & $<$ & 3.2 & $<$ & 4.0 \\
\hline $\mathrm{Er}$ & $<$ & 4.0 & $<$ & 8.1 & $<$ & 2.8 & $<$ & 3.4 \\
\hline Eu & $<$ & 2.3 & $<$ & 4.6 & $<$ & 4.8 & $<$ & 2.0 \\
\hline $\mathrm{F}$ & & 1.5 & & 1.0 & & 1.0 & & 1.3 \\
\hline $\mathrm{Fe}$ & & 2.2 & & 9.8 & & 10.0 & & 12.6 \\
\hline $\mathrm{Ga}$ & $<$ & 5.0 & $<$ & 2.0 & $<$ & 2.0 & $<$ & 5.0 \\
\hline $\mathrm{Gd}$ & $<$ & 5.6 & $<$ & 3.8 & $<$ & 4.0 & $<$ & 5.0 \\
\hline $\mathrm{Ge}$ & $<$ & 1.6 & $<$ & 1.1 & $<$ & 1.0 & $<$ & 1.4 \\
\hline $\mathrm{Hf}$ & $<$ & 15.6 & $<$ & 10.6 & $<$ & 3.6 & $<$ & 4.6 \\
\hline $\mathrm{Hg}$ & $<$ & 5.3 & $<$ & 3.6 & $<$ & 3.7 & $<$ & 4.6 \\
\hline Ho & $<$ & 1.2 & $<$ & 2.6 & $<$ & 0.9 & $<$ & 1.1 \\
\hline 1 & $<$ & 1.0 & $<$ & 2.0 & $<$ & 0.7 & $<$ & 2.6 \\
\hline In & $<$ & 0.9 & $<$ & 1.9 & $<$ & 0.6 & $<$ & 0.8 \\
\hline Ir & $<$ & 2.4 & $<$ & 1.6 & $<$ & 1.7 & $<$ & 2.1 \\
\hline K & & 1.6 & & 1.1 & & 1.2 & & 2.2 \\
\hline La & $<$ & 1.1 & $<$ & 2.2 & $<$ & 2.3 & $<$ & 2.9 \\
\hline Lu & $<$ & 1.4 & $<$ & 1.0 & $<$ & 1.0 & $<$ & 1.2 \\
\hline $\mathrm{Mg}$ & & 8.5 & & 11.6 & & 4.0 & & 15.0 \\
\hline$M n$ & & 1.2 & & 0.8 & & 0.9 & & 1.1 \\
\hline Mo & $<$ & 14.4 & $<$ & 9.8 & $<$ & 10.0 & $<$ & 12.7 \\
\hline
\end{tabular}

(1) By a 16-hour steam pyrohydrolysis of potassium fluoborate powder and recrystallization from demineralized water solution.

(2) Obtained commercially.

(3) Reagent-grade boric acid. 
Table 6 (Continued)

\begin{tabular}{|c|c|c|c|c|c|c|c|c|}
\hline \multirow{2}{*}{$\frac{\text { Element }}{\mathrm{Na}}$} & \multicolumn{2}{|c|}{$\begin{array}{l}\text { Laboratory } \\
\text { Prepared ( } 1 \text { ) }\end{array}$} & \multicolumn{2}{|c|}{$\begin{array}{l}\text { Technical } \\
\text { Grade (2) }\end{array}$} & \multicolumn{2}{|c|}{$\begin{array}{c}\text { Vendor } \\
A(3)\end{array}$} & \multicolumn{2}{|c|}{$\begin{array}{c}\text { Vendor } \\
B(3)\end{array}$} \\
\hline & & 0.9 & & 9.2 & & 0.6 & & 12.0 \\
\hline $\mathrm{Nb}$ & $<$ & 0.7 & $<$ & 0.5 & $<$ & 0.5 & $<$ & 0.6 \\
\hline $\mathrm{Nd}$ & $<$ & 4.8 & $<$ & 3.2 & $<$ & 3.0 & $<$ & 4.2 \\
\hline $\mathrm{Ni}$ & $<$ & 0.6 & & 0.6 & & 0.7 & $<$ & 0.6 \\
\hline Os & $<$ & 3.6 & $<$ & 2.4 & $<$ & 2.5 & $<$ & 3.2 \\
\hline$\Gamma$ & & 1.2 & & 0.8 & & 0.8 & & 1,1 \\
\hline $\mathrm{Pb}$ & $<$ & 3.1 & $<$ & 2.1 & $<$ & 6.5 & $<$ & 8.2 \\
\hline $\mathrm{Pd}$ & $<$ & 3.1 & $<$ & 2.1 & $<$ & 2.0 & $<$ & 2.7 \\
\hline $\operatorname{Pr}$ & $<$ & 1.1 & $<$ & 2.2 & $<$ & 0.8 & $<$ & 1.0 \\
\hline $\mathrm{Pt}$ & $<$ & 4.6 & $<$ & 3.1 & $<$ & 3.2 & $<$ & 4.0 \\
\hline $\mathrm{Rb}$ & $<$ & 0.9 & $s$ & 1.9 & $<$ & 0.6 & $<$ & 0.8 \\
\hline $\operatorname{Re}$ & $<$ & 2.3 & $<$ & 1.6 & $<$ & 1.6 & $<$ & 2.0 \\
\hline $\mathrm{Rh}$ & $<$ & 0.8 & $<$ & 0.6 & $<$ & 0.6 & $<$ & 0.7 \\
\hline Ru & $<$ & 2.5 & $<$ & 1.7 & $<$ & 1.8 & $<$ & 2.2 \\
\hline $\mathrm{Sb}$ & $<$ & 1.6 & $<$ & 3.4 & $<$ & 1.2 & $<$ & 1.4 \\
\hline $\mathrm{Sc}$ & & 1.1 & & 0.7 & & 0.7 & & 0.9 \\
\hline $\mathrm{Se}$ & & 3.8 & $<$ & 5.4 & $<$ & 2.8 & & 3.3 \\
\hline $\mathrm{Si}$ & & 42.6 & & 29.0 & & 15.0 & & 37.4 \\
\hline $\mathrm{Sm}$ & $<$ & 4.4 & $<$ & 3.0 & $<$ & 3.0 & $<$ & 3.9 \\
\hline Sn & $<$ & 33.0 & & 22.4 & $<$ & 23.0 & $<$ & 29.0 \\
\hline $\mathrm{Sr}$ & $<$ & 0.8 & $s$ & 1.7 & $<$ & 0.6 & $<$ & 0.7 \\
\hline $\mathrm{Ta}$ & $<$ & 4.2 & $<$ & 29.1 & $<$ & 45.0 & $<$ & 11.2 \\
\hline $\mathrm{Tb}$ & $<$ & 1.2 & $<$ & 0.8 & $<$ & 0.9 & $<$ & 1.1 \\
\hline $\mathrm{Te}$ & $<$ & 2.9 & $<$ & 2.0 & $<$ & 2.0 & $<$ & 2.6 \\
\hline Th & $<$ & 1.8 & $<$ & 3.7 & $<$ & 1.2 & $<$ & 1.6 \\
\hline $\mathrm{Ti}$ & & 2.4 & & 8.0 & & 5.4 & & 4.5 \\
\hline $\mathrm{TI}$ & $<$ & 2.2 & $<$ & 1.6 & $<$ & 1.6 & $<$ & 2.0 \\
\hline $\mathrm{Tm}$ & $<$ & 1.3 & $<$ & 0.9 & $<$ & 0.9 & $<$ & 1.2 \\
\hline$U$ & $<$ & 1.9 & $<$ & 3.8 & $<$ & 4.0 & $<$ & 1.6 \\
\hline V & $<$ & 0.4 & $<$ & 0.2 & $<$ & 0.3 & & 1.1 \\
\hline W & $<$ & 4.7 & $<$ & 3.2 & $<$ & 3.3 & $<$ & 4.2 \\
\hline$Y$ & $<$ & 0.7 & $s$ & 1.4 & $<$ & 0.5 & $<$ & 0.6 \\
\hline $\mathrm{Yb}$ & $<$ & 4.2 & $<$ & 2.9 & $<$ & 3.0 & $<$ & 3.8 \\
\hline $\mathrm{Zn}$ & & 3.2 & $<$ & 3.8 & & 3.9 & & 9.2 \\
\hline $\mathrm{Zr}$ & $\leq$ & 1.4 & $<$ & 1.0 & $<$ & 1.0 & $<$ & 1.2 \\
\hline Total (4) & & 105.7 & & 117.2 & & 142.2 & & 159.9 \\
\hline
\end{tabular}

(4) Exclusive of less-than values. 


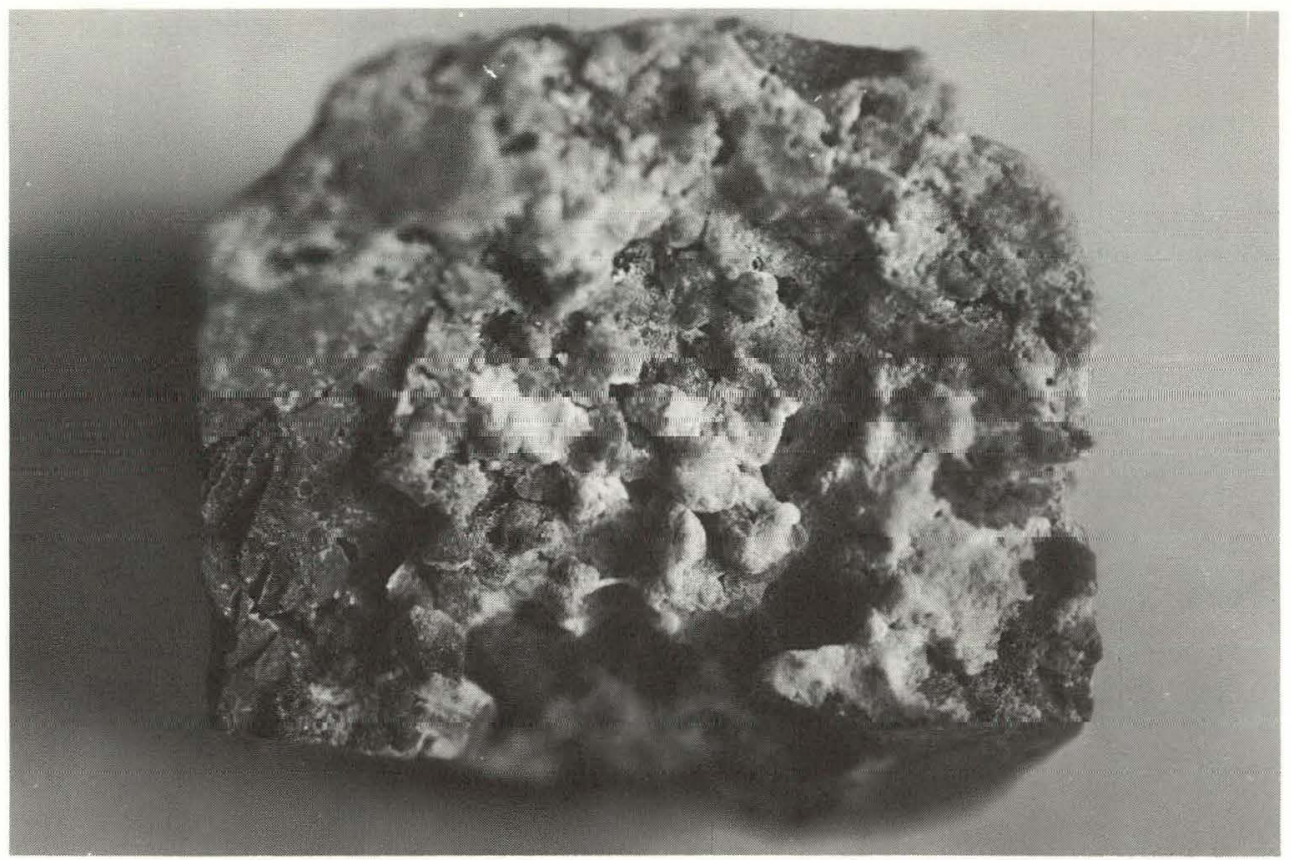

$S-68-5574-1$

Figure 6. PHOTOMICROGRAPH OF SINTERED BORON POWDER PARTIALLY OXIDIZED AT $900^{\circ} \mathrm{C} .(10 \mathrm{X})$

The steam pyrohydrolysis and boric acid recrystallization method thus appears to be very attractive for purifying impure elemental boron and boron compounds such as boric anhydride, potassium tluoborate, sodium tetraborate, or boron carbide $\left(\mathrm{B}_{4} \mathrm{C}\right)$. $(13)$

The following experimental program is suggested as a guideline for further development of the steam pyrohydrolysis and boric acid recrystallization method:

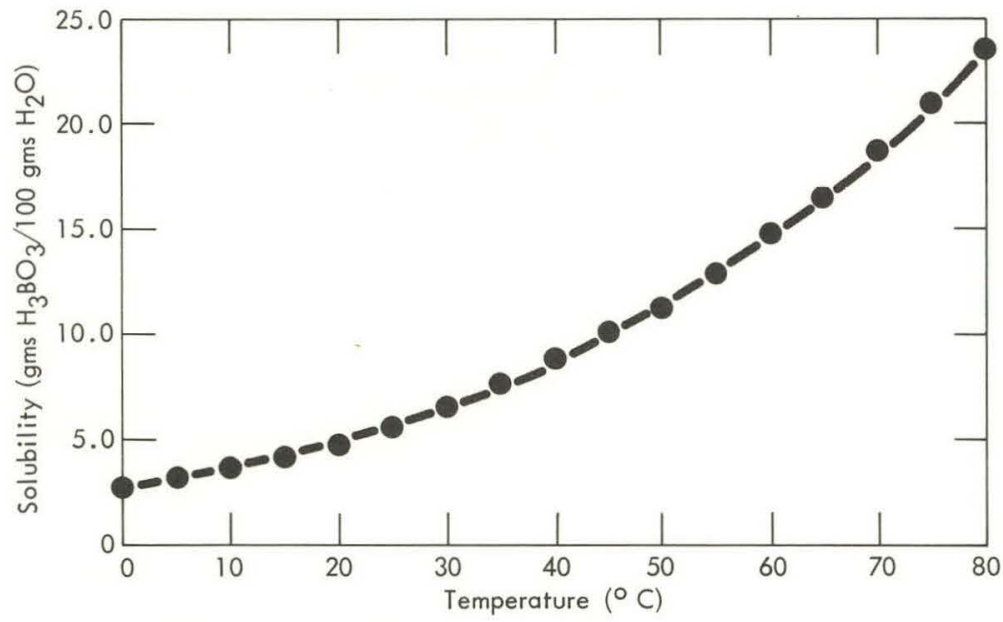

Figure 7. EFFECT OF TEMPERATURE ON THE SOLUBILITY OF BORIC ACID IN WATER. 
Table 7

AMERICAN CHEMICAL SOCIETY PURITY REQUIREMENTS FOR REAGENT-GRADE BORIC ACID

\begin{tabular}{|c|c|}
\hline Test Requirement & $\begin{array}{c}\text { Maximum } \\
\text { Amount } \\
(\%)\end{array}$ \\
\hline Insoluble in Methanol & 0.005 \\
\hline Nonvolatile with Methanol & 0.050 \\
\hline Chloride (as $\mathrm{Cl}^{-}$) & 0.001 \\
\hline Phosphate (as $\mathrm{PO}_{4}^{-3}$ ) & 0.001 \\
\hline Arsenic (as $\mathrm{As}^{+} 3$ ) & 0.0001 \\
\hline Calcium (as $\mathrm{Ca}^{+2}$ ) & 0.005 \\
\hline Heruy, Matrals (as $\mathrm{Ph}^{+2}$ ) & $n, n$ \\
\hline Iron (as $\mathrm{Fe}^{+3}$ ) & 0.001 \\
\hline Total ( $641 \mathrm{ppm})$ & 0.0641 \\
\hline
\end{tabular}

1. Initiate studies with impure boron carbide to optimize the conditions required for the complete pyrohydrolysis of the carbide and carbon according to the reactions:

$$
\begin{gathered}
\mathrm{B}_{4} \mathrm{C}+6 \mathrm{H}_{2} \mathrm{O} \stackrel{950^{\circ} \mathrm{C}}{\longrightarrow} 2 \mathrm{~B}_{2} \mathrm{O}_{3}+\mathrm{C}+6 \mathrm{H}_{2} \uparrow, \\
\mathrm{C}+\mathrm{H}_{2} \mathrm{O} \stackrel{950^{\circ} \mathrm{C}}{\longrightarrow} \mathrm{CO} \uparrow+\mathrm{H}_{2} \uparrow \text {, and } \\
\mathrm{C}+\mathrm{H}_{2} \mathrm{O} \stackrel{950^{\circ} \mathrm{C}}{\longrightarrow} \mathrm{CO}_{2} \uparrow+\mathrm{H}_{2} \uparrow .
\end{gathered}
$$

2. Initiate studies with uther irmpure boron compounds such as sodium tetraborate.

3. Optimize the effects of temperature, powder bed depth, use of air versus oxygen, and the ratio of steam to air or oxygen flow rates for various impure boron compounds.

4. Evaluate the degree of final purification obtained by aqueous recrystallization of boric acid compared to the recrystallization of boric acid from alcohol solutions.

5. Since fluoborates liberate boron fluoride $\left(\mathrm{BF}_{3}\right)$ upon heating, determine the extent of fluoride contamination in the aqueous condensate obtained 
by steam pyrohydrolysis and the degree of fluoride removal by ion-exchange treatment prior to boric acid recrystallization.

6. Evaluate the effect of using various ceramic and other materials of construction for the pyrohydrolysis reaction tube, the containment vessels for the impure boron-containing powders, and the steam condensation vessels on the degree of purity obtained. 


\section{REFERENCES}

(1) Soviet Research in Boron Chemistry, 1949-1956, p 220; Consultants Bureau, Inc, New York, New York.

(2) Niemyski, T. and Olempska, Z.; "The Preparation of Pure Boron for Semiconductor Investigations," J Less-Common Metals $\underline{=}$, pp 235-243 (1962).

(3) Trent, P. E.; Crystallization and Purification of Boron Metal Powder, Y-1614; Union Carbide Corporation-Nuclear Division, Oak Ridge Y-12 Plant, Oak Ridge, Tennessee; July 8, 1968.

(4) Ingles, T. A. and Popper, P.; Special Ceramics, pp 144-167; P. Popper, Editor, Academic Press, Inc, New York, New York (1960).

(5) Schmitt, C. R. and Edwards, R. K.; Preparation of High-Purity Boron Nitride Powder, $Y-1688$; Union Carbide Corporation-Nuclear Division, Oak Ridge Y-12 Plant, Oak Ridge, Tennessee; October 6, 1969.

(6) Mercuri, R. A. and Litz, L. M.; US Patent 3,240,563; March 15, 1966.

(7) Eberle, A. R., Pinto, L. J., and Lerner, M. W.; Boron Scrap Recovery by Pyrohydrolysis, NBL-206; New Brunswick Laboratory, New Brunswick, New Jersey; January 1964.

(8) Materials Protection 4, p 25; July 1965.

(9) Sherwin, E. and Weston, G. J.; Chemistry of the Non-Metallic Elements, p 179; Pergarrion Press, New York (1966).

(10) Brotherton, R. J. and Steinberg, H., Editors; Progress in Boron Chemistry, 3, p 178; Pergamon Press, New York, New York (1970).

(11) Adams, R. M., Editor; Boron, Metallo-Boron Compounds and Boranes, p 287; Interscience Publishers, New York, New York (1964).

(12) Reagent Chemicals, ACS Specification, PP $112-114$, 4th Edition; American Chemical Society, Washington, DC.

(13) Lerner, M. W.; The Analysis of Elemental Boron, US Atomic Energy Commission Division of Technical Information, p 12 (1970). 


\section{ACKNOWLEDGEMENTS}

The contributions of the following Y-12 Plant personnel are gratefully acknowledged: L. M. Steckel for the thermogravimetric-differential thermal analyses, R. A. Viator and H. L. Perdue for the X-ray diffraction analyses, and L. D. Keele for the boron analyses. 